\title{
Long Term Excessive Zn Supplementation Induced Oxidative Stress in Wistar Rats Fed on Semi-Synthetic Diet
}

\author{
Kshetrimayum Birla Singh
}

Department of Zoology, Pachhunga University College, Mizoram University, Aizawl, India.

Email: birla.kshetri@gmail.com

Received February $10^{\text {th }}, 2012$; revised March 29 ${ }^{\text {th }}, 2012$; accepted April $7^{\text {th }}, 2012$

\begin{abstract}
The use of $\mathrm{Zn}$ as micronutrient in husbandry and agriculture practices and also in baby foods and multivitamin supplements have been increased during the last two decades. However, the effect of long term increasing $\mathrm{Zn}$ load on the oxidative stress in the body has not been worked so far. The supplementation of pharmacological dosage of $\mathrm{Zn}$ in otherwise $\mathrm{Zn}$ adequate diet was investigated with the aim if excess $\mathrm{Zn}$ in the diet triggers oxidative stress and its conesquence on enzymes of antioxidant defense system. In this study, three groups of rats were fed on semi-synthetic diet containing $20 \mathrm{mg} \mathrm{Zn/kg} \mathrm{(control,} \mathrm{group-I),} 40 \mathrm{mg} \mathrm{Zn/kg} \mathrm{(group-II)} \mathrm{and} 80 \mathrm{mg} \mathrm{Zn/kg} \mathrm{(group-III)} \mathrm{diet} \mathrm{respectively} \mathrm{for} \mathrm{a}$ period of 6 months. Blood lipid profile in the serum, lipid peroxidation status and the activities of antioxidant enzymes and trace minerals level were estimated both in the liver and kidney of three groups of rats. The study revealed that the gain in body weight increased in rats in $\mathrm{Zn}$ concentration dependent manner. The blood lipid profile displayed a significant rise in serum glucose, total lipids, cholesterol, triglycerides, LDL-cholesterol, VLDL-cholesterol whereas HDL-cholesterol showed a reduction in their levels in group-II and III than their control counter parts. The lipid peroxidation products were higher and the enzyme activities of superoxide dismutase, catalase, glutathione-s-transferase, glutathione reductase, glutathione (reduced) and glucose-6-phosphate dehydrogenase were significantly lowered in liver and kidney of group-II and group-III. Their mineral status revealed a higher $\mathrm{Zn}$ concentration and lower $\mathrm{Cu}, \mathrm{Mg}$ and $\mathrm{Mn}$ both in liver and kidney. This data suggest that $\mathrm{Zn}$ in excess in diet when fed for longer periods of time induces oxidative stress by altering the status of minerals.
\end{abstract}

Keywords: Zn; Cu; Mg; Mn; Lipid Peroxidation; Antioxidant Enzymes; Oxidative Stress; Zn Supplementation

\section{Introduction}

Oxidative stress is the set of intracellular or extracellular conditions that leads to the chemical or metabolic generation of the reactive oxygen species (ROS), among which are highly reactive intermediates free radicals, such as superoxide anion $\left(\mathrm{O}_{2}^{-}\right)$, hydrogen peroxide $\left(\mathrm{H}_{2} \mathrm{O}_{2}\right)$, hydroxyl free radical $(\mathrm{OH})$, lipid peroxides [1]. It has become increasingly clear that oxidative stress plays a major role in the pathogenesis of a number of human diseases such as atherosclerosis, chronic renal failure, ischemia/reperfusion injury, neurodegenerative diseases, hypertension, cancer and diabetic micro and macro diseases [2]. In mammalian cells, there are several mechanisms in which organisms defend itself against oxidative stress. Among them, there are antioxidant scavenging enzymes such as cellular $\mathrm{Cu} / \mathrm{Zn}$ superoxide dismutase (SOD), catalase (CAT), glutathione peroxidase (GPx),
Glutathione-s-transferase (G-s-T), glutathione reductase (GRD), glucose-6-phosphate dehydrogenase (Glu-6-PD) and small molecular antioxidants such as reduced glutathione (GSH) [3]. As antioxidant enzymes have an important role in the protection against free radicals damage, a decreased in the activities or expression of these enzymes may predispose tissues to free radical damage. It has been reported that deficiency and excess of metals also promotes oxidative stress and lipid peroxidation [4]. The activities of $\mathrm{Cu}$ and $\mathrm{Zn}$ containing antioxidant enzymes including superoxide dismutase (SOD), cytochrome-C oxidase (CCO), catalase (CAT) and glutathione peroxidase (GPx) have been reported to diminish under $\mathrm{Zn}$ or $\mathrm{Cu}$-deficiency or due to alteration in $\mathrm{Cu}-\mathrm{Zn}$ ratio [5]. Moreover, activities of many enzymes are also influenced by $\mathrm{Mg}$ [6] and $\mathrm{Mn}$ status [7] and deficiencies or impairment in their metabolism may results an increased lipid peroxidation which possibly may be a con- 
tributory factor resulting in oxidative stress. $\mathrm{Zn}$ is an essential trace element and acts as indirect antioxidants via stabilization of cell membranes and the inhibition of free radicals production [8]. The importance of $\mathrm{Zn}$ is systematically considered for its role in $\mathrm{Cu} / \mathrm{Zn}$ SOD. Coudray et al. [9] found that experimental $\mathrm{Zn}$ deficiency causes a slight decreased in SOD activity accompanied by the increased production of the peroxidation lipids. On the contrary, there are increasing evidences that excessive $\mathrm{Zn}$ in diet induces obesity, diabetes, dyslipidemia and hypertension in experimental animals [10]. Higher concentration of $\mathrm{Zn}$ and lower concentration of $\mathrm{Cu}, \mathrm{Mg}$ and $\mathrm{Mn}$ in the tissues of human and some populations have been reported to link the ionic imbalance of nutritionally important elements to the etiology of diseases [11]. Moreover, excessive $\mathrm{Zn}$ intake by supplementation can impair immunologic function, interfere with metabolism of other essential minerals and other lipid indices [12]. Inspite of the fact that $\mathrm{Zn}$ is an essential micronutrient, the use of $\mathrm{Zn}$ supplement has been discourage by some health professional because excessive intake of $\mathrm{Zn}$ has been reported to induce $\mathrm{Cu}, \mathrm{Mg}, \mathrm{Mn}$ and $\mathrm{Fe}$ and Se deficiencies due their antagonistic interactions [13] and these minerals are required as cofactor for optimum catalytic activities and effective antioxidant defense mechanism of the body. During the past two decades, there has been a rise in the consumption of higher $\mathrm{Zn}$ either from $\mathrm{Zn}$ fortified foods as in the USA [14] or from vegetables (40 $\mathrm{mg} / \mathrm{kg}$ or more in above ground vegetables and 120 $\mathrm{mg} / \mathrm{kg}$ above in the underground vegetables) and meat foodstuffs $(102-165 \mathrm{mg} / \mathrm{kg})$ as in some States of India $[15,16]$ and this will further increase over time. As the population in these parts of the countries have been consuming excess amount of $\mathrm{Zn}$ through diet since a long period of time, the effect of such increasing $\mathrm{Zn}$ load in the body needs to be investigated by employing long term period of excess $\mathrm{Zn}$ supplementation just like in the real situation. It is believed that human individuals susceptible to many diseases are genetically predisposed to absorb or retain more $\mathrm{Zn}$ than their control counterparts like those of $\mathrm{db} / \mathrm{db}$ mice and Zucker rats and on spontaneous development of diseases they start losing $\mathrm{Zn}$ in their urine. They are associated with weak endogenous defense mechanisms to protect against harmful radical induced cell damage. This led us to investigate the real situation of the long term effect of increasing $\mathrm{Zn}$ load in the antioxidant enzymes status of the body. Therefore, the supplementation of pharmacological dosage of $\mathrm{Zn}$ in otherwise $\mathrm{Zn}$ adequate diet was investigated with the aim if excess $\mathrm{Zn}$ in the diet triggers oxidative stress and its consequence on enzymes of antioxidant defense system in rats which are not genetically predisposed to any diseases. The results of the present study are given in this communication.

\section{Materials and Methods}

For the present investigations a semi-synthetic basal diet rich in fat and refined sucrose was preferred over the standard pellet rat diet consisting of the natural ingredients to keep the consistency of the composition of diet particularly of fat, sucrose and micronutrients through out of the experiment and to rule out the possibility of Zn-interaction with fibers and phytates [17] which are known to reduced bioavailability of $\mathrm{Zn}$ by binding it in digestive tract and may take longer time duration of feeding to manifest the impact excessive $\mathrm{Zn}$ in diet. Accordingly, isocaloric semi-synthetic basal diet for the rats was prepared following modified Orgebin-crist et al. [18].

\subsection{Composition of Basal Diet}

It contained (g/100g of diet): casein, 30; agar, 2.00; corn oil, 5; cellulose, 8 ; sucrose, 51; *vitamin mixture, 0.5 and **mineral mixture, 3.5. [*Vitamin mixture $(\mathrm{mg} / \mathrm{kg})$ : Ascorbic acid, 500; biotin, 4; calcium-D-pentothenate, 320; choline chloride, 2500; folic acid, 10; inositol, 1000; nicotinic acid, 300; pyridoxine HCL, 80; riboflavin, 120; thiamin $\mathrm{HCl}, 200$; $\alpha$-tocopherol acetate (E), 60; cyanocobalamin, 0.40; retinol, 0.30; ergacalciferol, 0.0031 and **Mineral mixture (g/kg): $\mathrm{CaH}_{2} \mathrm{PO}_{4}, 25.30 ; \mathrm{COCl}_{3}, 0.04$; $\mathrm{CuCl}_{2}, 0.10 ; \mathrm{FeSO}_{4} \cdot 7 \mathrm{H}_{2} \mathrm{O}, 0.60 ; \mathrm{MnSO}_{4} \cdot \mathrm{H}_{2} \mathrm{O}, 0.31$; $\mathrm{MgSO}_{4} \cdot \mathrm{H}_{2} \mathrm{O}, 4.05 ; \mathrm{KCl}, 3.43 ; \mathrm{KI}, 0.004 ; \mathrm{Na}_{2} \mathrm{CO}_{3}, 1.15$; $\left.\mathrm{NaF}, 0.008 ; \mathrm{ZnSO}_{4} \cdot 7 \mathrm{H}_{2} \mathrm{O}, 0.088\right]$.

\subsection{Divisions of Diet}

The basal diet was further divided into 2 parts: control diet consisting of basal diet containing $20 \mathrm{mg} \mathrm{Zn} / \mathrm{kg}$ diet (per-se) for Group-I and $\mathrm{Zn}$-supplement-diet-I containing $40 \mathrm{mg} \mathrm{Zn} / \mathrm{Kg}$ diet for Group-II and $\mathrm{Zn}$ supplementeddiet-II containing $80 \mathrm{mg} / \mathrm{Zn}$ diet for Group-III by accordingly increasing $\mathrm{ZnSO}_{4} \cdot 7 \mathrm{H}_{2} \mathrm{O}$ in basal diet.

\subsection{Preparation of Diet}

For each diet, the mineral \& water-soluble vitamins were ground in sucrose and fat-soluble vitamins were dissolved in corn oil. Agar, which served as a binder and was dissolved in $25 \mathrm{ml}$ of triple distilled, deionized warm water $\left(60^{\circ} \mathrm{C}\right)$. On cooling to $40^{\circ} \mathrm{C}$, the contents of each diet were thoroughly mixed in agar solution in separate containers. The dough so formed was put in petridishes and solidified in refrigerator. The solidified diet was cut into small pieces of $2 \times 2 \times 2 \mathrm{~cm}$ size and stored in the container at the temperature $>-4^{\circ} \mathrm{C}$.

\subsection{Experimental Design}

Male wistar rats (30), aged 6 weeks, weighing $60-70$ g 
was procured from Central Animal House, Panjab University, Chandigarh. They were maintained in plastic cages with stainless steel top grill at room temperature $\left(25^{\circ} \mathrm{C}-28^{\circ} \mathrm{C}\right)$ with $10: 14 \mathrm{hr}$ L:D cycles of $70 \%-80 \%$ $\mathrm{RH}$ as per guide lines of Institutional Animals Ethics Committee. They were fed on standard pellet rat feed for one week to acclimatize. Thereafter, the rats were divided into 3 groups-I, II and II and in such a way that their mean initial body weights remained almost similar in each group. The animals were fed on their respective diets ad libitium and triple distilled deionised water was made freely available to them for 180 days. The body weights were recorded at the beginning of the dietary treatment and thereafter every week. After the end of the dietary treatment of 180 days, the male rats of each group were sacrificed using diethyl ether as anesthesia.

\subsection{Assessment of Blood Lipid Profile}

The blood samples were collected by puncturing the heart and blood serum was prepared by centrifuging blood at $2500 \mathrm{rpm}$ for 15 minutes. The freshly prepared serum was analyzed for cholesterol [19] triglycerides [20], HDL-cholesterol [21] (all by using commercially available kits-Reckon Diagnostic Pvt, Ltd., Baroda, India and ERBA diagnostic Mannheim $\mathrm{GmbH}$, Mannheim, Germany, supplied through Transasia Bio-Medicals LTD, Daman) and total lipids [22]. The LDL and VLDL-cholesterol was calculated by Friedwald's equation [23].

\subsection{Assessments of Lipid Peroxidation and Antioxidant Enzymes Status in the Liver and Kidney}

The liver and kidney of three groups of rats were removed for the study of enzyme activities. For this purpose, their homogenates were prepared in $50 \mathrm{mM}$ TrisHCL buffer $(\mathrm{pH} 7.4)$ and then centrifuged at $1000 \mathrm{~g}$ for 10 minute at $4{ }^{\circ} \mathrm{C}$ to remove nuclie and debris. Supernatant was again centrifuged at $1000 \mathrm{~g}$ for 30 minute to obtain post mitochondrial supernatant (PMS). The levels of lipid peroxidation (LPO) products were evaluated by the method of Beuge and Aust [24] and glutathione (reduced) (GSH) by the method of Ellman [25] in their PMS fraction. Activities of superoxide dismutase (SOD) [26] catalase (CAT) [27], glutathione-s-transferase (Glu$\mathrm{s}-\mathrm{T}$ ) [28] glutathione reductase (GRD) [29] and glucose6-phosphate dehydrogenase (G-6-PD) [30] were estimated in PMS of liver and kidney. Protein was evaluated as per of Lowry et al. [31].

\subsection{Estimation of Minerals in Liver and Kidney}

$\mathrm{Zn}, \mathrm{Cu}, \mathrm{Mg}$ and $\mathrm{Mn}$ were estimated on atomic absorption spectrophotometer (Electronic Corporation of India Lim- ited, Hyderabad-AAS 4139) using hollow cathode lamps $(213.9 \mathrm{~nm}, 324.8 \mathrm{~nm}, 285.2 \mathrm{~nm}$ and $279.5 \mathrm{~nm}$ for $\mathrm{Zn}, \mathrm{Cu}$, $\mathrm{Mg}$ and $\mathrm{Mn}$ respectively). Samples of liver and kidney are digested separately in 3:1 v/v nitric acids and perchloric acids on a sand bath until a white ash formed. The ash was dissolved in $6 \mathrm{ml}$ of $10 \mathrm{mM} \mathrm{HNO}_{3}$ and filtered through ash free filter paper before analysis. Standards of $\mathrm{Zn}, \mathrm{Cu}, \mathrm{Mg}$ and $\mathrm{Mn}$ from Sigma Chemical Co., USA were prepared by dilution in triple distilled deionised water (TDW).

\subsection{Statistical Analysis}

The values are presented as means \pm standard error of the mean (SEM). One way ANOVA was used to determine whether treatment groups differed significantly with control group. Differences were considered significant when $\mathrm{P}<0.05$.

\section{Results}

\subsection{Changes in Body Weight}

The results of this study revealed a significant rise in monthly body weights $(\mathrm{P}<0.001)$ in group-II and groupIII up to a dietary treatment of 150 days ( 5 months). After that a significant decreased in body weights was observed in group-II and group-III after the next 30 days of dietary treatment (Table 1).

\subsection{Changes in Blood Profile}

After six month of the dietary treatment, a significant rise in serum glucose, total lipids, cholesterol, triglycerides, VLDL-c, LDL-c $(\mathrm{P}<0.001)$ was observed with a significant decreased $(\mathrm{P}<0.001)$ in serum HDL-c in groupII and group-III revealing alteration in blood lipid metabolisms in excess $\mathrm{Zn}$ supplemented groups (Table 2).

Table 1. Month wise body weight of male rats of group-I, group-II and group-III during 180 days of dietary treatment [Values are mean $\pm S E$ of 6 observation each].

\begin{tabular}{cccc}
\hline $\begin{array}{c}\text { Time duration } \\
\text { (in days) }\end{array}$ & $\begin{array}{c}\text { Group-I } \\
\text { (Control) }\end{array}$ & Group-II & Group-III \\
\hline $\mathbf{0}$ & $68.0 \pm 0.68$ & $67.0 \pm 0.67$ & $67.2 \pm 0.79$ \\
$\mathbf{3 0}$ & $164.5 \pm 1.12$ & $195.5 \pm 1.13^{\mathrm{a}}$ & $235.6 \pm 1.67^{\mathrm{a}}$ \\
$\mathbf{6 0}$ & $198.17 \pm 1.53$ & $274.67 \pm 1.67^{\mathrm{a}}$ & $298.5 \pm 1.14^{\mathrm{a}}$ \\
$\mathbf{9 0}$ & $265.6 \pm 1.97$ & $320.33 \pm 1.70^{\mathrm{a}}$ & $365.3 \pm 0.860^{\mathrm{a}}$ \\
$\mathbf{1 2 0}$ & $282.50 \pm 1.70$ & $348.4 \pm 1.60^{\mathrm{a}}$ & $385.5 \pm 1.39^{\mathrm{a}}$ \\
$\mathbf{1 5 0}$ & $325.67 \pm 1.13$ & $360.57 \pm 1.78^{\mathrm{a}}$ & $415.5 \pm 1.67^{\mathrm{a}}$ \\
$\mathbf{1 8 0}$ & $372.5 \pm 0.82$ & $335.83 \pm 1.10^{\mathrm{a}}$ & $355.67 \pm 1.67^{\mathrm{a}}$ \\
\hline
\end{tabular}

Units: gram; P values: ${ }^{\mathrm{a}}<0.001$ (values of group-II and group-III were compared with group-I) 
Table 2. Blood lipid profile of male rats of group-I, groupII and group-III during 180 days of dietary treatment [Values are mean \pm SE of 6 observation each].

\begin{tabular}{|c|c|c|c|}
\hline Parameters & $\begin{array}{l}\text { Group-I } \\
\text { (Control) }\end{array}$ & Group-II & Group-III \\
\hline Total Lipids (mg/dl) & $205.50 \pm 2.14$ & $250.17 \pm 1.78^{\mathrm{a}}$ & $315.33 \pm 2.86^{\mathrm{a}}$ \\
\hline Cholesterol (mg/dl) & $61.67 \pm 2.17$ & $82.0 \pm 1.02^{\mathrm{a}}$ & $115.0 \pm 1.86^{\mathrm{a}}$ \\
\hline $\begin{array}{l}\text { Triglycerides } \\
\text { (mg/dl) }\end{array}$ & $63.67 \pm 1.56$ & $104.83 \pm 1.76^{\mathrm{a}}$ & $121.67 \pm 2.67^{\mathrm{a}}$ \\
\hline $\begin{array}{l}\text { VLDL-Cholesterol } \\
\text { (mg/dl) }\end{array}$ & $12.7 \pm 0.320$ & $20.97 \pm 0.360^{\mathrm{a}}$ & $24.3 \pm 0.340^{\mathrm{a}}$ \\
\hline $\begin{array}{l}\text { HDL-Cholesterol } \\
\text { (mg/dl) }\end{array}$ & $24.67 \pm 1.12$ & $14.67 \pm 0.710^{\mathrm{a}}$ & $10.83 \pm 0.410^{\mathrm{a}}$ \\
\hline $\begin{array}{l}\text { LDL-Cholesterol } \\
\text { (mg/dl) }\end{array}$ & $28.27 \pm 1.35$ & $48.37 \pm 0.760^{\mathrm{a}}$ & $81.83 \pm 1.94^{\mathrm{a}}$ \\
\hline
\end{tabular}

\subsection{Lipid Peroxidation and Antioxidant Enzymes Status}

The LPO products in group-II and III were found to be significantly higher $(\mathrm{P}<0.001)$ in liver and kidney of group-II and III than the control group-I showing weak antioxidant defense system in former than the latter group. Their higher levels in group-II and III coincided with enzymes of antioxidant defense system i.e. SOD, CAT, Glu-s-T, GRD, GSH and Glu-6-PD whose activities were evaluated significantly less $(\mathrm{P}<0.001 ; \mathrm{P}<0.05)$ in these groups after six months of dietary treatment (Tables 3 and 4 ).

\subsection{Changes in Minerals Status}

The difference in the activities of the enzymes of antioxidant system and lipid peroxidation coincided with difference in mineral status in different groups. $\mathrm{Zn}$ concentration was higher $(\mathrm{P}<0.001)$ and $\mathrm{Cu}, \mathrm{Mg}$ and $\mathrm{Mn}$ concentrations were significantly lowered $(\mathrm{P}<0.001)$ in the liver and kidney of the group-II and III than the control group-I showing ionic imbalances in them (Table 5).

\section{Discussion}

The increase in body weight in three groups of rats varied significantly with the increase in $\mathrm{Zn}$ concentration in diet during the first 150 days of dietary treatment and thereafter it fell in group-II and III during the next 30 days with respect to their weight at 150 days than their control group-I at day 180 of the experiment. It suggests that $\mathrm{Zn}$ is highly potent nutrient which initially promotes the gain in body weight in concentration dependent manner but reduced body weights when such intakes are continued for a prolonged period as revealed in group-II
Table 3. Mean lipid peroxidation and enzymes activities in liver of male rats of group-I, group-II and group-III during 180 days of dietary treatment [Values are mean \pm SE of 6 observation each].

\begin{tabular}{|c|c|c|c|}
\hline Parameters & $\begin{array}{l}\text { Group-I } \\
\text { (Control) }\end{array}$ & Group-II & Group-III \\
\hline $\begin{array}{l}\text { Lipid peroxidation (nmol } \\
\text { MDA produced/hr/mg } \\
\text { protein) }\end{array}$ & $0.74 \pm 0.05$ & $0.99 \pm 0.04^{\mathrm{a}}$ & $1.61 \pm 0.19^{\mathrm{a}}$ \\
\hline $\begin{array}{l}\text { Superoxide dismutase } \\
\text { (unit/mg protein) }\end{array}$ & $15.10 \pm 0.20$ & $10.4 \pm 0.16^{\mathrm{a}}$ & $7.57 \pm 0.27^{\mathrm{a}}$ \\
\hline $\begin{array}{c}\text { Catalase }\left(\mu \mathrm{mol} \mathrm{H}_{2} \mathrm{O}_{2}\right. \\
\text { decomposed } / \mathrm{min} / \mathrm{mg} \\
\text { protein })\end{array}$ & $51.77 \pm 0.93$ & $40.08 \pm 0.68^{\mathrm{a}}$ & $32.03 \pm 1.25^{\mathrm{a}}$ \\
\hline $\begin{array}{l}\text { Glutathione-s-transferase } \\
\text { ( } \mu \text { mol of CDNB-GSH } \\
\text { conjugate formed } / \mathrm{min} / \mathrm{mg} \\
\text { protein) }\end{array}$ & $0.640 \pm 0.02$ & $0.590 \pm 0.04^{b}$ & $0.542 \pm 0.02^{\mathrm{a}}$ \\
\hline $\begin{array}{l}\text { Glutathione (reduced) } \\
\text { (nmol GSH/mg/protein) }\end{array}$ & $8.23 \pm 0.16$ & $6.77 \pm 0.17^{\mathrm{a}}$ & $3.42 \pm 0.11^{\mathrm{a}}$ \\
\hline $\begin{array}{l}\text { Gutathione reductase } \\
\text { (nmol NADPH } \\
\text { oxidized/min/mg protein) }\end{array}$ & $7.63 \pm 0.24$ & $4.98 \pm 0.12^{\mathrm{a}}$ & $3.40 \pm 0.34^{\mathrm{a}}$ \\
\hline $\begin{array}{l}\text { Glucose-6-phosphate } \\
\text { dehydrogenase (nmol } \\
\text { NADPH formed/min/mg } \\
\text { protein) }\end{array}$ & $10.20 \pm 0.45$ & $6.22 \pm 0.24^{\mathrm{a}}$ & $3.57 \pm 0.13^{\mathrm{a}}$ \\
\hline
\end{tabular}
with group-I)

Table 4. Mean lipid peroxidation and enzymes activities in kidney of male rats of group-I, group-II and group-III during 180 days of dietary treatment [Values are mean \pm SE of 6 observation each].

\begin{tabular}{|c|c|c|c|}
\hline Parameters & $\begin{array}{l}\text { Group-I } \\
\text { (Control) }\end{array}$ & Group-II & Group-III \\
\hline $\begin{array}{c}\text { Lipid peroxidation } \\
\text { (nmol MDA } \\
\text { produced/hr/mg protein) }\end{array}$ & $0.66 \pm 0.03$ & $0.84 \pm 0.02^{\mathrm{a}}$ & $1.21 \pm 0.03^{\mathrm{a}}$ \\
\hline $\begin{array}{l}\text { Superoxide dismutase } \\
\text { (unit/mg protein) }\end{array}$ & $12.07 \pm 0.16$ & $10.12 \pm 0.11^{\mathrm{a}}$ & $8.40 \pm 0.14^{\mathrm{a}}$ \\
\hline 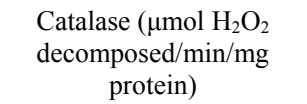 & $42.80 \pm 0.78$ & $36.10 \pm 0.47^{\mathrm{a}}$ & $31.75 \pm 1.60^{\mathrm{a}}$ \\
\hline $\begin{array}{c}\text { Glutathione-s-transferase } \\
\text { ( } \mu \text { mol of CDNB-GSH } \\
\text { conjugate formed } / \mathrm{min} / \mathrm{mg} \\
\text { protein) }\end{array}$ & $0.540 \pm 0.03$ & $0.520 \pm 0.04^{b}$ & $0.470 \pm 0.02^{\mathrm{a}}$ \\
\hline $\begin{array}{l}\text { Glutathione (reduced) } \\
\text { (nmol GSH/mg/protein) }\end{array}$ & $7.62 \pm 0.22$ & $4.35 \pm 0.17^{\mathrm{a}}$ & $3.63 \pm 0.32^{\mathrm{a}}$ \\
\hline $\begin{array}{l}\text { Gutathione reductase } \\
\text { (nmol NADPH } \\
\text { oxidized/min/mg protein) }\end{array}$ & $6.37 \pm 0.16$ & $4.93 \pm 0.24^{\mathrm{a}}$ & $1.22 \pm 0.24^{\mathrm{a}}$ \\
\hline $\begin{array}{l}\text { Glucose-6-phosphate } \\
\text { dehydrogenase (nmol } \\
\text { NADPH formed } / \mathrm{min} / \mathrm{mg} \\
\text { protein) }\end{array}$ & $6.83 \pm 0.57$ & $4.78 \pm 0.19^{\mathrm{a}}$ & $2.85 \pm 0.31^{\mathrm{a}}$ \\
\hline
\end{tabular}


Table 5. Mean Zinc (Zn), Copper (Cu), Magnesium (Mg) and Manganese (Mn) concentration in the liver and kidney of male rats of group-I, group-II and group-III during 180 days of dietary treatment (Values are mean \pm SE of $10 \mathrm{ob}-$ servation each).

\begin{tabular}{cccc}
\hline Parameters & $\begin{array}{c}\text { Group-I } \\
\text { (Control) }\end{array}$ & Group-II & Group-III \\
\hline Liver $\mathrm{Zn}(\mu \mathrm{g} / \mathrm{g}$ tissue) & $34.7 \pm 0.88$ & $45.1 \pm 0.84^{\mathrm{a}}$ & $55.0 \pm 0.65^{\mathrm{a}}$ \\
Liver $\mathrm{Cu}(\mu \mathrm{g} / \mathrm{g}$ tissue $)$ & $62.3 \pm 0.68$ & $45.9 \pm 1.13^{\mathrm{a}}$ & $34.3 \pm 0.77^{\mathrm{a}}$ \\
Liver $\mathrm{Mg}(\mu \mathrm{g} / \mathrm{g}$ tissue $)$ & $60.0 \pm 1.03$ & $47.0 \pm 0.49^{\mathrm{a}}$ & $36.0 \pm 0.90^{\mathrm{a}}$ \\
Liver $\mathrm{Mn}(\mu \mathrm{g} / \mathrm{g}$ tissue $)$ & $40.80 \pm 0.59$ & $30.40 \pm 0.65^{\mathrm{a}}$ & $26.90 \pm 0.66^{\mathrm{a}}$ \\
Kidney $\mathrm{Zn}(\mu \mathrm{g} / \mathrm{g}$ tissue) & $38.4 \pm 0.54$ & $43.7 \pm 0.69^{\mathrm{a}}$ & $52.1 \pm 1.52^{\mathrm{a}}$ \\
Kidney $\mathrm{Cu}(\mu \mathrm{g} / \mathrm{g}$ tissue $)$ & $48.5 \pm 0.74$ & $36.50 \pm 0.68^{\mathrm{a}}$ & $30.10 \pm 0.63^{\mathrm{a}}$ \\
Kidney $\mathrm{Mg}(\mu \mathrm{g} / \mathrm{g}$ tissue $)$ & $52.50 \pm 0.84$ & $43.90 \pm 0.54^{\mathrm{a}}$ & $36.20 \pm 0.76^{\mathrm{a}}$ \\
Kidney $\mathrm{Mn}(\mu \mathrm{g} / \mathrm{g}$ tissue $)$ & $42.80 \pm 1.87$ & $35.90 \pm 0.94^{\mathrm{a}}$ & $25.20 \pm 0.62^{\mathrm{a}}$ \\
\hline
\end{tabular}

P values: ${ }^{a}<0.001$ (values of group-II and group-III were compared with group-I).

and group-III in the present investigations (Table 1). This observation is consistent as observed by Taneja et al. [32] who had discussed at length the mechanism of induction of this disorder in the rats induced by $\mathrm{Zn}$ and also reported by others [33]. It also lends support to the report that an increase of $\mathrm{Zn}$ in diet to double the amount of recommended dietary allowances (RDA) increases the portion of body fat during 25 weeks period of dietary treatment in healthy children [34]. The blood lipid profile of treated rats revealed significant rise of total lipids, cholesterol, triglycerides, VLDL-c and LDL-c and decreased HDL-c after 180 days of $\mathrm{Zn}$ supplementation in group-II and group-III as compared to the control group-I (Table 2). These observations are in agreement with previous reports from both human and animal studies wherein supplementation of $\mathrm{Zn}$ increased blood cholesterol (both LDL and VLDL-c) and decreased in HDLcholesterol level $[35,36]$. This alterations in blood lipid profiles in the $\mathrm{Zn}$ treated group-II and III in the present investigations may be resulted from deficiencies of $\mathrm{Cu}$, $\mathrm{Mg}$ and $\mathrm{Mn}$ in the tissues as a consequence of high $\mathrm{Zn}$ supplementation. The assessment of the metal status in the present study showed that $\mathrm{Cu}, \mathrm{Mg}$ and $\mathrm{Mn}$ were approximately up to $30 \%$ less in group-II and up to $50 \%$ less in group-III rats both in liver and kidney indicating the induction of the $\mathrm{Cu}, \mathrm{Mg}$ and $\mathrm{Mn}$ deficiencies or rise in ratios of $\mathrm{Zn}$ to $\mathrm{Cu} / \mathrm{Mg} / \mathrm{Mn}$ in the tissues. The observed increase of plasma cholesterol by increasing dietary $\mathrm{Zn}$ at all levels of $\mathrm{Cu}$ suggests that dietary $\mathrm{Zn}$ seems to suppress the plasma cholesterol lowering effect of dietary $\mathrm{Cu}$ [37] as a result of the increased in the activity of liver enzyme, 3-hydroxy-3 methylglutamate coenzyme A re- ductase [38], the rate limiting enzyme in cholesterol biosynthesis and decrease in the lipoprotein lipase, hepatic lipase and lecithin cholesterol acyltransferase (ICAT) activity [39]. Experimental $\mathrm{Mg}$ deficiency has also been shown to increase triglycerides, cholesterol, VLDL, LDL rich lipoproteins and reduced HDL-c [40], almost similar to $\mathrm{Cu}$ deficiency. In $\mathrm{Mg}$ deficient animals, hypertriglyceridemia could have arisen as a consequence of increased synthesis of triglycerides in the liver, decreased removal of lipid from the blood or combination of both. An increased in the HDL-c concentration is closely associated with triglyceride metabolism and defective triglyceride removal from the plasma compartment might explain low HDL-c level as found in the present investigations. One more possible mechanism for the alteration of lipid levels is due to Mn-deficient in these animals which resulted an increased of lipid peroxidation in the endoplasmic reticulum, which is the site of lipoprotein synthesis. Bell and Hurley [41], observed swollen and irregular endoplasmic reticulum in tissues of Mn-deficient mice. This suggests that the observed rise in level of cholesterol, triglycerides, VLDL-c and LDL-c and reduction in HDL$\mathrm{c}$ in the group-II and III rats in the present investigations resulted due to $\mathrm{Cu}$ deficiency couple with $\mathrm{Mg}$ and $\mathrm{Mn}$ deficiencies in tissues caused by excessive $\mathrm{Zn}$ intake in diet. The LPO products was found to be higher in the liver and kidney of group-II and III rats than those of the control group-I showing weak antioxidant defense system in the former $\mathrm{Zn}$ supplemented groups in the present study. The production of lipid peroxidation products depends on activities of antioxidant enzymes such as SOD, CAT, Glu-s-T, GRD, GSH and Glu-6-PD which registered a significant reduction in liver and kidney of group-II and group-III rats (Tables 3 and 4). Since the group-II and group-III rats are displaying alteration in blood lipid metabolisms, as expected the lipid peroxidation products were higher in them than those of control rats indicating that the rats are under the oxidative stress. To control lipid peroxidation, there is defensive system consisting of antioxidant enzymes that play an important role in scavenging reactive oxygen species. The organism's susceptibility to free radical stress and peroxidation stress is related to balance between free radical load and adequacy of antioxidant defenses. The decrease in SOD and CAT activities in the group-II and III rats in the present study may be attributed to exhaustion/inactivation possibly due to $\mathrm{Cu}$ and $\mathrm{Mn}$ deficiencies induced by high $\mathrm{Zn}$ intake in diet. Our results are in agreement with Cousins [42] and Strain [43] who reported that increased $\mathrm{Zn}$ intake reduces the activities of important antioxidant like SOD and CAT by limiting the bioavailability of $\mathrm{Cu}$ and increased LPO products in tissue [44]. SOD and CAT constitute principal component of antioxidant enzymes system and a decreased in the activities/expression 
of these enzymes can result in oxidative stress by increasing LPO products [2] as found in the $\mathrm{Zn}$ treated group-II and III rats in the present investigations. Decreased activity of Glu-s-T in the present study suggests a reduction in availability of the substrate GSH which was recorded also in low level in the $\mathrm{Zn}$ treated group-II and III rats than the control group-I. The decreased GSH level in group-II and group-III rats could be due to decreased synthesis, increased consumption or increased loss through efflux during oxidative stress. In conformity of our results, other studies also has been reported depletion of GSH level due to inhibition of oxidized glutathione (GSSG) reductase by excess $\mathrm{Zn}$ [45]. As a result of oxidative stress in group-II and III, the hexose monophosphate shunt (HMS) might have been impaired, so NADPH availability has been reduced and the ability to recycled GSSG to GSH by GRD might have been decreased. GRD catalyzes NADPH dependent reduction of oxidized glutathione serving to maintain intracellular glutathione stores and a favorable redox status [46]. Therefore, these changes in the redox status could be considered particular sensitive indicative of oxidative stress in the $\mathrm{Zn}$ supplemented group-II and III found in the present investigations. The difference in the activities of the enzymes of antioxidant defense system and LPO products coincided with the difference in mineral status in different groups of rats. The assessment of mineral status in group-II and III revealed an ionic imbalance wherein $\mathrm{Zn}$ concentration in liver and kidney were higher and that of $\mathrm{Cu}, \mathrm{Mg}$ and $\mathrm{Mn}$ were lowered compared to their control counterpart (Table 5). As a consequence of this, the activities of all the enzymes investigated were decreased in the group-II and III rats which in turn led to an increase of the LPO products in their respective groups. This ionic imbalance may be attributed to the overexpression of $\mathrm{Zn}$-metallothieonien during high $\mathrm{Zn}$ treatment period. As a result, they absorbed and retained greater amount of $\mathrm{Zn}$ than the control counterpart leading to the deficiencies of $\mathrm{Cu}, \mathrm{Mg}$ and $\mathrm{Mn}$ due to their negative interactions as found in the present study [47]. The present data of minerals status indicated that $\mathrm{Zn}$ in excess even in pharmacological doses in diet over a period of time replaces $\mathrm{Cu}, \mathrm{Mg}$ and $\mathrm{Mn}$ leading to their leaching and sloughing and excretion in the urine even if these metals are adequate in diet. And the deficiencies/imbalance of these elements are link to subsequent development of dyslipidemia and oxidative stress as observed in present study since these metallic ions being integral components of enzymes such as SOD, CAT, and GPx.

\section{Conclusion}

The data of the study showed that the depletion of the antioxidant defence system may be compensatory mecha- nisms against oxidative stress induced by high $\mathrm{Zn}$ intake in diet in treated rats which causes ionic imbalance of metals required for proper functioning of antioxidant enzymes. The results of the present study thus provide strong evidences that excessive $\mathrm{Zn}$ in diet even in pharmacological doses induced oxidative stress. Since oxidative stress play a major role in the pathogenesis of number of human diseases like atherosclerosis, diabetic micro and macro diseases, hypertension, cancer and obesity related diseases etc., the rising prevalence of diseases per se during past two decades may not essentially be due to changes in the lifestyle but also may be associated with the genetic predisposition from excessive $\mathrm{Zn}$ absorption or food intake through food chain due to its liberal use as $\mathrm{ZnSO}_{4}$ in agriculture and animal husbandry practices employed by the farmers, $\mathrm{Zn}$ rich dietary supplements, $\mathrm{Zn}$ fortified foods and low amount of $\mathrm{Zn}$ binding protein such as fibres and phytates in diet. Thus, there appear to be oxidative stress related consequences of such pharmacological doses of $\mathrm{Zn}$ particularly when such intakes are continued for a prolonged period.

\section{Acknowledgements}

Thanks are due to Prof. S. Chaudhary, former Chairman, Department of Zoology, Panjab University, Chandigarh, for providing the necessary laboratory facilities. Financial assistance to Ksh. Birla Singh under support schemes of Minor Research Project by University Grant Commission-North Eastern Regional Office (UGC-NERO), Guwahati, is gratefully acknowledged.

\section{REFERENCES}

[1] P. Saltman, "Oxidative Stress: A Radical View," Seminars in Hematology, Vol. 26, 1989, pp. 249-256.

[2] J. M. Mates, Z. C. Perez-Gome, D. Nunez and I. Castro, "Antioxidant Enzymes and Human Diseases," Clinical Biochemistry, Vol. 32, No. 8, 1999, pp. 595-603. doi:10.1016/S0009-9120(99)00075-2

[3] M. Kasapoglu and T. Ozben, "Alteration of Antioxidant Enzymes and Oxidative Stress Makers in Aging," Experimental Gerontology, Vol. 36, 2001, pp. 209-220. doi:10.1016/S0531-5565(00)00198-4

[4] K. Hirayam and A. Yasutake, "Free Radicals and Trace Elements," Journal of Trace Elements in Experimental Medicine, Vol. 11, No. 2-3, 1998, pp. 209-217.

[5] J. R. Prohaska, "Changes in $\mathrm{Cu}, \mathrm{Zn}$-Superoxide Dismutase, Cytochrome-C Oxidase, Glutathione Peroxidise and Glutathione Transferase Activities in Copper Deficient Mice and Rats," Journal of Nutrition, Vol. 121, No. 3, 1991, pp. 355-363.

[6] G. Paolisso, A. Scheen, F. D’Onofrio and P. Lefebvre, "Magnesium and Glucose Homeostasis," Diabetologia, Vol. 33, No. 9, 1990, pp. 511-514. doi:10.1007/BF00404136 
[7] D. I. Paynter, "The Role of Dietary Copper, Manganese, Selenium and Vitamin-E in Lipid Peroxidation in Tissue of Rats," Biological Trace Element Research, Vol. 2, 1980, pp. 121-135. doi:10.1007/BF02798591

[8] T. M. Bray and W. J. Bettger, "The Physiological Role of Zinc as Antioxidant," Free Radical Biology and Medicine, Vol. 8, 1990,pp. 281-291. doi:10.1016/0891-5849(90)90076-U

[9] C. Coudray, M. J. L. Richard, F. Laported, P. Faure, A. M. Roussel and A. E. Favier, "Superoxide Dismutase Activity and Zn Status: A Study in Man and Animals," Journal of Nutrition, Vol. 3, 1993, pp. 13-26.

[10] D. Pomp, A. M. Oberbauer and J. D. Murray, "Growth and Body Composition of OMT-la-OGH Transgenic Male Mice with Differing Periods of Transgenic Activation," Journal of Animal Science, Vol. 70, No. 1, 1992, pp. 198-201.

[11] S. K. Taneja and R. Mandal, "Assessment of Minerals in Obesity Related Diseases in Chandigarh (India) Population," Biological Trace Element Research, Vol. 121, No. 2, 2008, pp. 106-123. doi:10.1007/s12011-007-8035-1

[12] A. B. Abdel-Mageed and F. W. Oehme, "A Review of the Biochemical Roles, Toxicity and Interactions of Zinc, Copper and Iron," Veterinary and Human Toxicology, Vol. 32, 1990, pp. 34-39.

[13] J. Aaseth, M. Haugen and O. C. Forre, "Rheumatoid Arthritis and Metal Components-Perspective on the Role of Oxygen Radical Detoxification," Analyst, Vol. 123, 1998, pp. 3-6. doi:10.1039/a704840h

[14] J. E. Arsenault and K. H. Brown, "Zn Intake of US Preschool Children Exceeds New Dietary References Intakes," American Journal of Clinical Nutrition, Vol. 8, 2003, pp. 1011-1016.

[15] B. Ram, S. P. Garg and S. S. Matharu, "Effect of Contaminants in Wastewater on Soil and Vegetables-A Case Study," Panjab Pollution Control Board, 2005.

[16] K. B. Singh and S. K. Taneja, "Concentration of Zn, Cu and $\mathrm{Mn}$ in Vegetables and Meat Foodstuffs Commonly Available in Manipur: A North Eastern State of India," Electronic Journal of Environmental, Agricultural and Food Chemistry, Vol. 9, No. 3, 2010, pp. 610-616.

[17] D. Oberleas and B. F. Herland, "Phytate Content of Foods: Effect on Dietary Zinc Bioavailability," Journal of the American Dietetic Association, Vol. 79, 1981, pp. 433436.

[18] M. C. Orgebincrist, M. Freeman and G. H. Barney, "Sperm Formation in Zn-Deficient Rats," Annals of Biochem Biophys, Vol. 11, 1971, pp. 547-558. doi:10.1051/rnd:19710403

[19] P. Roeschlau, E. Bernt and W. A. Gurber, "Enzymatic Determination of Total Cholesterol in Serum," Journal of Clinical Chemistry \& Clinical Biochemistry, Vol. 1974, 1974, pp. 232-266.

[20] M. W. McGowan, J. D. Artiss, D. R. Stranberg and B. A. Zak, "Peroxide Coupled Method for Colorimetric Determination of Serum Triglycerides," Clinical Chemistry, Vol. 29, 1983, pp. 438-542.

[21] M. Burstein, H. R. Schonick and R. Morfin, "Rapid
Method for the Isolation of Lipoproteins from Human Serum by Precipitation with Polyanions," Journal of Lipids Research, Vol. 11, 1970, pp. 583-595.

[22] C. S. Frings and R. T. Dunn, "A Calorimetric Method for Determination of Total Serum Lipids Based on Sulpha-Phosphovanillin Reaction," American Journal of Clinical Pathology, Vol. 53, 1970, pp. 89-91.

[23] W. T. Friedewald, R. I. Levy and D. S. Fredrickson, "Estimation of Concentration of LDL-Cholesterol in Plasma without Use of Preparative Ultracentrifuge," Clinical Chemistry, Vol. 18, No. 6, 1972, pp. 499-502.

[24] J. A. Beuge and S. D. Aust, "Microsomal Lipid Peroxidation," Method Enzymology, Vol. 52, 1978, pp. 302-310. doi:10.1016/S0076-6879(78)52032-6

[25] G. L. Ellman, "Tissue Sulphydryl Groups," Archives of Biochemistry and Biophysics, Vol. 82, 1959, pp. 70-77. doi:10.1016/0003-9861(59)90090-6

[26] M. Nishikimi, N. A. Rao and K. Yagi, "The Occurrence of Superoxide Anion in the Reaction of Reduced Phenazine Methosulphate and Molecular Oxygen," Biochemical and Biophysical Research Communications, Vol. 46, No. 2, 1972, pp. 849-859. doi:10.1016/S0006-291X(72)80218-3

[27] A. E. Aebi, "Catalase," In: H. V. Bergnmeyer, Ed., Methods of Enzymatic Analysis, 3rd Edition, Vol. 3, Academic Press, New York, 1983, pp. 273-386.

[28] W. Habig, M. J. Pabst and W. B. Jackboy, "Glutathione-s-Transfrase. The First Enzymatic Step in Mercapturic Acid Formation," Journal of Biological Chemistry, Vol. 249, 1974, pp. 7130-7139.

[29] H. D. Horn, "Glutathione Reductase," In: H. V. Bergmeyer, Ed., Methods of Enzymatic Analysis, Academic Press, New York, 1971, pp. 875-881.

[30] G. W. Lohr and H. D. Waller, "Glucose-6-Phosphate Dehydrogenase," In: H. V. Bergmeyer, Ed., Methods of Enzymatic Analysis, Academic Press, New York, 1963, p. 744.

[31] O. H. Lowry, N. J. Rosebrough, A. L. Farr and R. J. Randall, "Protein Measurement with the Folin Phenol Reagent," Journal of Biological Chemistry, Vol. 193, 1951, pp. 265-275.

[32] S. K. Taneja, R. Mandal and S. Girhotra, "Long Term Excessive Zn Supplementation Promotes Metabolic Syndrome-X in Wistar Rats Fed Sucrose and Fat Rich Semi-Synthetic Diet," Indian Journal of Experimental Biology, Vol. 44, 2006, pp. 705-718.

[33] M. D. Chen, P. Y. Lin, V. Cheng and W. H. Lin, "Zinc Supplementation Aggravates Body Fat Accumulation in Genetically Obese Mice and Dietary Obese Mice," Biological Trace Element Research, Vol. 52, No. 2, 1996, pp. 125-132. doi:10.1007/BF02789454

[34] A. Prentice, "Does Mild Zn Deficiency Contributes to Poor Growth Performance," Nutrition Reviews, Vol. 5, 1993, pp. 268-270.

[35] P. L. Hooper, L. Visconti, P. I. Garry and G. E. Johnson, "Zinc Lowers High Density Lipoprotein Cholesterol Levels," JAMA, Vol. 244, No. 17, 1980, pp. 1960-1961. doi:10.1001/jama.1980.03310170058030 
[36] R. K. Chandra, "Excessive Intake of Zn Impairs Immune Responses," JAMA, Vol. 252, No. 11, 1984, pp. 14431446. doi:10.1001/jama.1984.03350110043027

[37] L. M. Klevay, "The Effect of Zinc to Copper on Cholesterol Metabolism," American Journal of Clinical Nutrition, Vol. 28, 1975, pp. 764-768.

[38] N. Y. Yount, D. J. Mc Namara, A. Al-Othman and K. Y. Lei, "The Effect of Copper Deficiency on Rat Hepatic 3 Hydroxy-3 Methylglutaryl Coenzyme-A Reductase Activity," Journal of Nutritional Biochemistry, Vol. 1, No. 1, 1990, pp. 21-27. doi:10.1016/0955-2863(90)90094-2

[39] B. W. C. Lau and L. M. Klevay, "Plasma Lecithin: Cholesterol Acyltrasnferase in Copper Deficient Rats," Journal of Nutrition, Vol. 111, 1981, pp. 1698-1703.

[40] Y. Rayssiguier and E. Gueux, "Magnesium and Lipids in Cardiovascular Diseases," Journal of the American College of Nutrition, Vol. 5, 1986, pp. 507-562.

[41] L. T. Bell and L. S. Hurley, "Ultrastructural Effects of Manganese Deficiency in Liver, Heart, Kidney and Pancreas of Mice," Lab Invest, Vol. 29, 1973, pp. 723-736.

[42] R. J. Cousins, "Absorption, Transport and Hepatic Metabolism of Copper and Zinc: Special Reference to Metallothionein and Ceruloplasmin," Physiological Reviews, Vol. 65, 1985, pp. 238-309.
[43] J. J. Strain, "Newer Aspects of Micronutrients in Chronic Diseases: Copper," Proceedings of the Nutrition Society, Vol. 53, No. 3, 1994, pp. 583-598. doi:10.1079/PNS19940067

[44] P. S. Balevska, E. M. Russanov and T. A. Kasabova, "Studies of Lipid Peroxidation in Rat Liver by Copper Deficiency," International Journal of Biochemistry, Vol. 13, 1981, pp. 489-493. doi:10.1016/0020-711X(81)90122-1

[45] M. O. Steinebach and H. T. Wolterbeck, "Effect of Zn on Rat Hepatoma HTC Cells and Primary Cultured Rat Hepatocytes," Toxicology and Applied Pharmacology, Vol. 118, No. 2, 1993, pp. 245-254. doi:10.1006/taap.1993.1030

[46] B. Mannervik and U. H. Danielson, "Glutathione-sTransferase-Structure and Catalytic Activity," Critical Reviews in Biochemistry, Vol. 23, 1988, pp. 283-337. doi: $10.3109 / 10409238809088226$

[47] P. Irato, A. Giacon, R. D. Margo, C. Mestriner and V. Albergoni, "Effect of $\mathrm{Zn}$ Supplementation on Metallothionein, Copper and Zinc Concentration in Various Tissues of Copper Loaded Rats," Biological Trace Element Research, Vol. 51, 1996, pp. 87-95. doi:10.1007/BF02790151

\section{Abbreviations and Acronyms}

ROS: reactive oxygen species;

HDL: high density lipoprotein;

LDL: low density lipoprotein;

VLDL: very low density lipoprotein;

LPO: lipid peroxidation;

NADPH: reduced adenine dinucleotide phosphate. 